\title{
THE UNEMPLOYMENT OF HIGHLY EDUCATED PEOPLE IN ROMANIA. A PANEL VAR APPROACH
}

\author{
Mihaela Simionescu* \\ Institute for Economic Forecasting of the Romanian Academy, Bucharest, Romania, \\ Centre for Migration Studies in Prague Business School, Prague, Czech Republic, \\ E-mail: mihaela.simionescu@ipe.ro
}

\section{Maria-Simona Naroș}

School of Advanced Studies of the Romanian Academy, Bucharest, Romania, E-mail: simona.naros@yahoo.com

\section{(Received: February 2019; Accepted: April 2019; Published: August 2019)}

\begin{abstract}
The insertion of graduates of higher education on the labor market is one of the problems faced by the Romanian labor market. Based on a VAR model in the panel, the number of unemployed with higher education in Romania is explained in correlation with variables related to the educational environment. As the number of graduates, the number of teaching staff and the number of faculties increase the unemployment rate among people with higher education also increases slightly, showing that they have not immediately integrated into the labor market. A shock (an innovation) in the series of unemployed numbers results in an increase in the number of unemployed and a long-term stabilization of the influence to positive values. A shock to the data series on the number of graduates, the number of faculties and teaching staff does not have an immediate effect on the number of unemployed with higher education.
\end{abstract}

Keywords: unemployment, panel VAR model, higher educated graduates, faculties

JEL Codes: J21, J24, C53

\section{Introduction}

The rapid dynamics of society raises major issues in the educational, social and economic field. The answers to these problems must allow their solution on the one hand and, on the other, create the possibility of subsequent economic and social development. The main aim of this paper is to explain the unemployment among

\footnotetext{
* Corresponding author: Mihaela Simionescu. E-mail: mihaela.simionescu@ipe.ro

Copyright @ 2019 The Author(s). Published by VGWU Press

This is an Open Access article distributed under the terms of the Creative Commons Attribution License - Non Commercial - NoDerivs License (http://creativecommons.org/licenses/by-nc-nd/3.0/) which permits unrestricted use, distribution, and reproduction in any medium, provided the original author and source are credited.
} 
Simionescu, M., Naroș M.S., (2019)

The unemployment of highly educated people in Romania. A panel VAR approach

higher-educated people from Romania based on other variables related to education.

For this macroeconomic analysis, specific research methods will be applied. The analysis of macroeconomic data on the number of unemployed with higher education and the number of higher education graduates aims at applying a vectorautoregressive model (VAR) in the panel and a model with random effects. This method is proper for this situation, when small volume data sets are available. As we have regional data on unemployment rates, faculty numbers, teaching staff and the number of higher education graduates between 1993 and 2017, a panel approach in a vector-autoregressive model (VAR) will be used. This type of model is useful also from the point of view of the Granger causality relationships between variables. The purpose of applying these methods is to explain the phenomenon of unemployment among graduates of higher education, and to suggest, on the basis of the results, some recommendations for a better integration of individuals with higher education in the Romanian labor market.

The novelty elements of this paper are given by the results of empirical analysis at macroeconomic level using appropriate quantitative methods, as well as suggestions for improving the insertion of graduates on the labor market based on these empirical results.

The results of the regional analysis based on the VAR model in the panel suggest difficulties in integrating the graduates of higher education into the Romanian labor market, as confirmed by other studies in the literature by a microeconomic approach (Naroș, 2018) or by a macroeconomic approach (Bălan, 2014).

Recommendations proposed on the basis of quantitative analysis should be taken into account by governmental decision makers who, through appropriate legislative measures, must achieve the objective of sustainable development by supporting quality education at the level of education in general and higher education in particular. Measures are needed to reconfigure educational programs or to promote teaching strategies that require the involvement of young people in educational projects. In this sense, the internship platform would ensure the necessary dialogue between the actors involved in the training programs: candidates, companies and universities.

\section{Literature review}

Sustainable development, along-term objective pursued by any national economy, also means ensuring a high level of employment and, implicitly, reducing the unemployment rate to the value of natural unemployment rate. This can be achieved by promoting the partnership public-private partnership that can stimulate job creation where productivity is high (Zaman, 2006). Revenue redistribution 
Simionescu, M., Naroş M.S., (2019)

The unemployment of highly educated people in Romania. A panel VAR approach

mechanisms are needed to avoid giving social assistance to people who do not want to work, although they have the ability to work.

Adaptation of individuals to changes in social systems occurring in every evolutionary period of society, and especially to changes occurring at the level of the education system, can be relatively easy. Any transformation changes at one time was perceived as a paradigm shift, with inevitable effects both within the school institutions, at the community level and even at the individual level. Regarding the education system, various models have been developed over time, different effects interactions and responses have been sought as pertinent to problems arising both inside and outside the system. Any success in resolving the problems of the education system was a step forward in putting into practice the drawn conclusions, as any failure triggered the elaboration of new models to respond effectively and more elaborately to the current challenges.

At the end of the 1970s, the insertion of young people into the labor market was a matter of concern for both the academic community and decision-makers in more developed countries. (Freeman, 1979; Clark and Summers, 1982; Ellwood, 1992; Berger, 1989). Although a series of measures have been implemented to facilitate the transition of young people from school to work, their entry into the labor market has become increasingly difficult. Initially, this phenomenon was associated with the surplus transient job offer given by the high birth rate after the Second World War (baby boomers generations. When the youth unemployment rate continued to rise despite declining cohorts, studies focused on labor market and educational system dysfunctions.

At the end of the 1990s and the early 2000s, with the doubling of the unemployment rate among the younger population in developed countries compared to the previous decade (Blanchflowerand and Oswald, 1998; Blanchflower and Freeman, 2000), the issue of youth integration into the labor market became one of the most critical challenges for public policy at national and international level and a problem of great interest in literature (Blanchflower and Oswald, 1998; Blanchflower and Freeman, 2000; Korenman and Neumark, 2000; Jimeno and Rodriguez-Palenzuela, 2002; O ' Higgins, 2003; Quintini and Martin 2006).

The recent economic crisis has made it more difficult for young people to find a place on the labour market, due to the high sensitivity to macroeconomic developments, as previously demonstrated in the studies by Blanchflower and Freeman (2000), Jimeno and Rodriguez-Palenzuela (2002) O'Higgins (2003) and OECD (2008).

In recent years, amid socio-economic developments at global level and sustainability as an objective, the specialists in the field, but also policy makers

22 S sciendo Studia Universitatis "Vasile Goldis" Arad. Economics Series Vol 29 Issue 3/2019 ISSN: 1584-2339; (online) ISSN: 2285 - 3065

Web: publicatii.uvvg.ro/index.php/studiaeconomia. Pages $20-37$ 
Simionescu, M., Naroş M.S., (2019)

The unemployment of highly educated people in Romania. A panel VAR approach

and international organizations, have analyzed in detail the characteristics, risk factors, costs and consequences at individual and social levels related to the difficulties of insertion into the labor market, to find viable solutions. Empirical and theoretical studies cover the global, national or regional levels (OCDE, 2010; Bell \& Blanchflower, 2011; Symonds et al., 2011; Vasile \& Vasile, 2011; Bălan et al., 2013; Macmillan 2012; Dietrich, 2012; Hawley et al., 2012; Ball \& Maguire, 2013).

The labor market for young people in Romania is characterized by the employment deficit, the number of jobs and the falling wages. Moreover, youth unemployment has specific vulnerabilities such as: a growing sensitivity to macroeconomic developments, long periods of unemployment, the difficulty of creating jobs for young people, an easier insertion into the informal labor market (Braica, 2015). Romania is the EU country with the highest unemployment among young people, and the recent economic crisis has accentuated the number of precarious workplaces(with low wages, below the skills of young people), the incidence of poverty, long-term unemployment and the depreciation of skills.

Young people remain the most vulnerable category to unemployment. Although Romania has a level of youth participation in education close to the EU average, this level is the smallest of the new EU Member States. The limited funds allocated to education and their inefficient use adversely affect the quality of the education system.

\section{Methodology and empirical data}

The empirical research aims at building a vector-autoregressive model (VAR) in the panel. For the estimation of this model, data was downloaded from the Tempo database of the National Institute of Statistics (NIS) for the period 1993-2017 for the eight regions of Romania (North-West, Center, North-East, South-East, South Muntenia, Bucharest-Ilfov, South-West Oltenia, West): the number of unemployed, the number of license graduates, the teaching staff in higher education and the number of faculties. For the number of graduates (with a Bachelor's degree) data is available only until 2015.

The number of graduates refers to the end of the academic year, and graduates are considered students who have passed the last year of college, regardless of whether they passed the final graduation exam. For the number of licensed graduates, no data is available for 2017, therefore the panel with which we will work is unbalanced.

Teaching staff in higher education includes individuals in higher education who teach in the process of education and training, both full-time and part-time. Teacher registration is done only once and only at the university where it has the basic norm. 
Simionescu, M., Naroș M.S., (2019)

The unemployment of highly educated people in Romania. A panel VAR approach

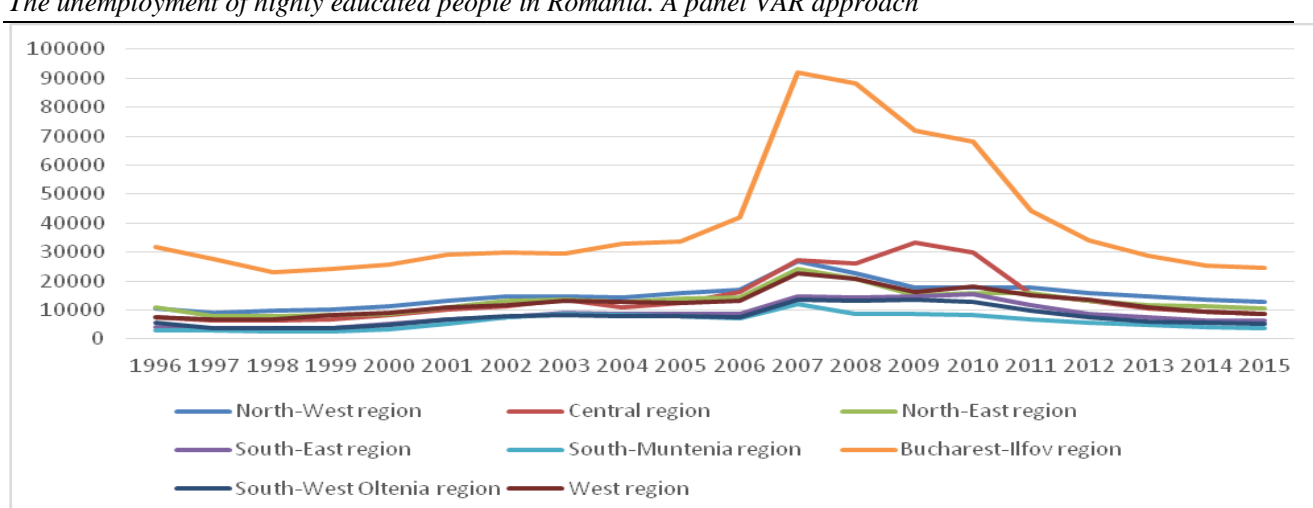

Figure 1 Evolution of the number of graduates (with a bachelor's degree) in the regions of Romania during the period 1996-2015

Source: author's graph

As can be seen from Figure 1, the Bucharest-Ilfov region is the one that supplies most graduates with a Bachelor's degree in Romania, achieving a maximum level of graduates in 2007, which is almost a tripling (an increase of $189.29 \%$ ) of the number of graduates compared to 1996. After 2007 the indicator decreses, which is in line with the general decrease of university graduates at a national level. Given that there is a significant gap between the number of graduates from the BucharestIlfov region and that in the other regions, a separate analysis of the regions is necessary, excluding the Bucharest-Ilfov region.

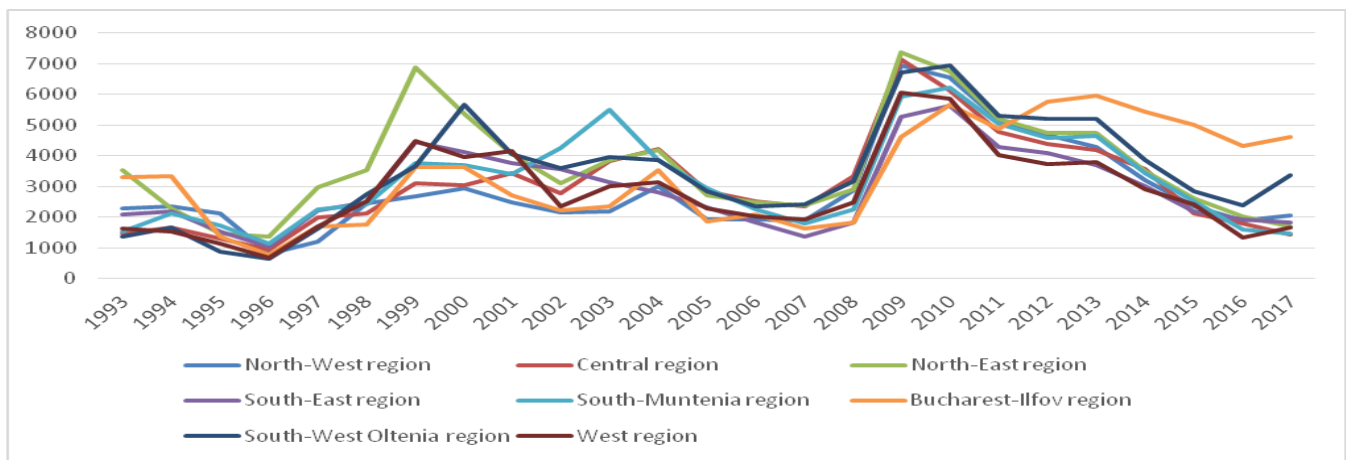

Figure 2 Evolution of the number of unemployed people with university studies in the regions of Romania in the period 1996-2017

Source: author's graph 
Simionescu, M., Naroş M.S., (2019)

The unemployment of highly educated people in Romania. A panel VAR approach

As can be seen in Figure 2, starting with 2012, most of the unemployed with higher education are concentrated in the Bucharest-Ilfov region, which provides the most graduates with a Bachelor's degree in Romania, reaching a maximum level of unemployed with higher education in 2013. In 2009, when the economic crisis was already in place in Romania, the North-East region, the poorest in the country had the most unemployed with higher education, so that in 2010 and 2011 the SouthWest Oltenia region would feel the most acute the issue of unemployment among university graduates.

The data series related to the number of unemployed with higher education by region in the period 1993-2017 is characterized by the following indicators (Table $1)$ :

Table 1 Indicators for characterization of the number of unemployed with university studies

\begin{tabular}{|l|l|l|l|l|l|l|l|l|}
\hline & $\begin{array}{c}\text { North } \\
\text { West }\end{array}$ & Center & $\begin{array}{c}\text { North } \\
\text { East }\end{array}$ & $\begin{array}{c}\text { South } \\
\text { East }\end{array}$ & $\begin{array}{c}\text { South } \\
\text { Muntenia }\end{array}$ & $\begin{array}{c}\text { Bucharest } \\
\text { Ilfov }\end{array}$ & $\begin{array}{c}\text { South } \\
\text { West } \\
\text { Oltenia }\end{array}$ & $\begin{array}{c}\text { West } \\
\text { Average }\end{array}$ \\
\hline Median & 1501.222 & 1807.111 & 3271.444 & 3199.333 & 2335.667 & 5744.111 & 4511.333 & 3128 \\
\hline Maximum & 3348 & 1697 & 3025 & 3016 & 2399 & 5636 & 4584 & 2844 \\
\hline Minimum & 886 & 638 & 2159 & 1924 & 1354 & 4282 & 3006 & 1481 \\
\hline $\begin{array}{l}\text { Standard } \\
\text { deviation }\end{array}$ & 894.037 & 840.013 & 792.932 & 863.985 & 601.804 & 941.342 & 1054.896 & 1289.167 \\
\hline Asymmetry & 1.069 & -0.238 & 0.215 & -0.131 & 0.027 & 0.284 & 0.060 & 0.186 \\
\hline Excess & 2.562 & 1.542 & 1.781 & 1.584 & 2.388 & 2.375 & 1.675 & 1.654 \\
\hline $\begin{array}{l}\text { Jarque-Bera } \\
\text { statistics }\end{array}$ & 1.786 & 0.883 & 0.626 & 0.778 & 0.142 & 0.268 & 0.664 & 0.731 \\
\hline Probability & 0.409 & 0.643 & 0.731 & 0.678 & 0.932 & 0.875 & 0.717 & 0.694 \\
\hline
\end{tabular}

Source: own processing in EVIEWS

The Jarque-Bera test (JB) applied to the cross-section number of unemployed (by region) does not reject the assumption of normality of data distribution at the materiality threshold of $5 \%$ for all cross-sections.

The panel VAR model is useful to apply in this case as the problem of a small set of data through the panel approach is solved, but it is also possible to identify the causal relations in the Granger sense between variables on stationary data. Based on VAR models, the effect of a shock (innovations) on a variable on the other variables in the system is measured (Simionescu, 2013).

The general form of a VAR model is shown below:

$y_{n, t}=\mu_{n}+A_{n}(i) \cdot Y_{n, t-1}+\varepsilon_{n, t^{\prime}}(1)$ 
Simionescu, M., Naroş M.S., (2019)

The unemployment of highly educated people in Romania. A panel VAR approach

$Y_{n, t}=\left(y_{1 t^{\prime}}, y_{2 t^{\prime}}, \ldots, y_{N t^{\prime}}\right)$ includes data for all units (regions), $\mathrm{n}=1,2, \ldots, \mathrm{N}$

$y_{n, t^{-}}$vector of variables for each spatial unit (region)

$\mu_{n}$ - unit-specific intercept

$A_{n}(L)$ - the delay polynomial with the coefficients of the VAR model

$\varepsilon_{n, t^{\prime}}$ disturbances (mean 0 and variance $\sigma_{n}^{2}$ )

If an unrestricted model is estimated, matrix $A_{n}$ includes $\mathrm{N} \mathrm{x} \mathrm{k} \mathrm{x} \mathrm{N} \mathrm{coefficients.}$

According to Goodhart and Hofmann (2008), links between space units are neglected in the traditional panel VAR model. The approach proposed by Canova and Ciccarelli (2006) will be considered, where the VAR model is redesignated to take into account the links between the spatial units (regions). Various linear combinations of explanatory variables are used to synthesize changes to regressors. The traditional fixed-effect estimator is not consistent in dynamic models if the coefficients of dependent variables differ across spatial units. Autocorrelation of errors is caused by limitations on coefficients when regressions are autocorelated. Estimation based on instrumental variables does not solve the problem of serial correlation. Therefore, Pesaran and Smith (1995) recommend the estimation with the group average estimator. Coefficients along spatial units are calculated based on the average, to have consistent estimates of average effects.

Coefficients in $A_{n}(L)$ vary randomly across transverse units under the group average estimator assumptions. The standard element $a_{n, i, j}^{p}$ of $A_{n}(L)$ is: $a_{n, i, j}^{p}=$ $a_{i, j}^{p}+\mu_{n, i, j}^{p}$, where $\mathrm{p}$ is the lag of the VAR model, $\mathrm{p}=1,2, \ldots, \mathrm{P}$, and $\mathrm{n}$ is the spatial unit index, $\mathrm{i}, \mathrm{j}=1,2, \ldots, \mathrm{K}$.

The reduced form of the VAR in the panel is:

$y_{n, t}=\mu_{n}+A_{n}(L) \cdot y_{n, t}+\varepsilon_{n, t \prime}(2)$

The purpose of applying these methods is to explain the phenomenon of unemployment among graduates of higher education, in order to suggest some recommendations for their better insertion into the Romanian labor market.

\section{Empirical results and discussion}

Pearson correlation coefficients suggest a weak and negative linear relationship between the number of unemployed with higher education and the rest of the variables (number of graduates, faculties and teaching staff), but there is a strong correlation between the number of faculties and the number of teaching staff, and also between the number of graduates graduates and the number of faculties, which is in line with expectations (Appendix).

Since the data series for all variables are stationary in the panel, a VAR model is built into the panel (VAR (3)). For the choice of lag (1) the principle of parsimony

26 S sciendo Studia Universitatis "Vasile Goldis" Arad. Economics Series Vol 29 Issue 3/2019 ISSN: 1584-2339; (online) ISSN: 2285 - 3065

Web: publicatii.uvvg.ro/index.php/studiaeconomia. Pages $20-37$ 
Simionescu, M., Naroș M.S., (2019)

The unemployment of highly educated people in Romania. A panel VAR approach

was applied: between two competing models the simplest is chosen. Thus, we chose a VAR model in the 1st order panel at the expense of a 4th model (Appendix).

The built model meets the conditions of stability. The polynomial roots of the autoregressive process are shown below (Table 2):

Table 2 Polynomial roots of autoregressive process

\begin{tabular}{|c|c|}
\hline root & module \\
\hline 0.770194 & 0.770194 \\
\hline-0.43356 & 0.433558 \\
\hline 0.334546 & 0.334546 \\
\hline-0.01885 & 0.018848 \\
\hline
\end{tabular}

Source: own processing in EViews

The exclusion test, Wald type, suggests that in the VAR model (1) in the panel, all lags are significant for all variables (Table 3 ):

Table 3 The lag exclusion test

\begin{tabular}{|l|l|l|l|l|l|}
\hline & UNEMPLOYED & GRADUATES & TEACHING STAFF & FACULTIES & Common \\
\hline Lag 1 & 257.9026 & 16.27785 & 39.37732 & 35.10987 & 334.0559 \\
\hline & {$[0.000000]$} & {$[0.002668]$} & {$[5.82 \mathrm{e}-08]$} & {$[4.41 \mathrm{e}-07]$} & {$[0.000000]$} \\
\hline
\end{tabular}

Source: own processing in EViews

For the proposed model, the errors are homoscedastic and independent, but their distribution is not normal at a significance level of 5\%, as suggested by the results in Appendix 1. From an economic point of view, it is useful for this valid model to analyze the pulse-response function and the decomposition of variables on variance.

Starting from the VAR model (1) in the panel the effect of an impulse (shock) that emerged in one of the teaching staff variables, graduates and faculties on the number of unemployed with higher education (Table 8 and Table 9) is analyzed.

A shock (an innovation) in the series of the number of unemployed leads to an increase in the number of unemployed and a long-term stabilization of the influence to positive values. A shock to the data series on the number of graduates, the number of faculties and teaching staff does not have an immediate effect on the number of unemployed with higher education. Only in the second period the shock on the time series for these variables leads to an increase in the number of unemployed and a long-term stabilization of the influence to positive values (see Table 4). In other words, there are long-term difficulties in inserting the unemployed with higher education into the labor market, as suggested by Bălan et al. (2013). 
Simionescu, M., Naroş M.S., (2019)

The unemployment of highly educated people in Romania. A panel VAR approach

Table 4 Response of the number of unemployed with higher education to a shock in variables (1993-2017)

\begin{tabular}{|r|r|r|r|r|}
\hline \multicolumn{1}{|l|}{ Period } & UNEMPLOYED & \multicolumn{1}{l|}{ GRADUATES } & \multicolumn{1}{l|}{ TEACHING STAFF } & \multicolumn{1}{l|}{ FACULTIES } \\
\hline 1 & 932.2144 & 0 & 0 & 0 \\
\hline 2 & 675.3487 & 141.1185 & 202.9675 & 80.60454 \\
\hline 3 & 524.6887 & 78.44241 & 54.68993 & 93.9677 \\
\hline 4 & 396.8095 & 80.56225 & 84.03061 & 82.47922 \\
\hline 5 & 307.0143 & 55.72929 & 45.78349 & 67.11978 \\
\hline 6 & 235.2632 & 46.46901 & 43.21661 & 52.8057 \\
\hline 7 & 181.5191 & 34.52244 & 29.75095 & 41.08208 \\
\hline 8 & 139.5995 & 27.22892 & 24.41769 & 31.7615 \\
\hline 9 & 107.5856 & 20.72432 & 18.14486 & 24.51029 \\
\hline 10 & 82.82534 & 16.07905 & 14.25866 & 18.8904 \\
\hline
\end{tabular}

Source: own processing in EViews

A shock (an innovation) in the series of higher education graduates leads to an immediate increase in the number of graduates, then a decrease in the values of this variable. In the long term, the influence of negative values is stabilized. A shock at the level of the number of faculties and teaching staff does not have any immediate effect on the number of graduates. Only in the second period, the shock to the number of faculties determines an increase in the number of graduates, and the sixth period tends to decrease the number of graduates of higher education (see Table 5).

Table 5 Response of the number of graduates (license) to a variable shock (1993-2017)

\begin{tabular}{|r|r|r|r|r|}
\hline \multicolumn{1}{|c|}{ Period } & UNEMPLOYED & GRADUATES & \multicolumn{1}{l|}{ TEACHING STAFF } & \multicolumn{1}{l|}{ FACULTIES } \\
\hline 1 & -641.769 & 13081.5 & 0 & 0 \\
\hline 2 & -504.744 & -1032.67 & -3181.83 & 1485.091 \\
\hline 3 & -647.973 & 609.2498 & 1218.591 & 403.7563 \\
\hline 4 & -264.07 & -235.494 & -644.72 & 104.2533 \\
\hline 5 & -268.225 & 72.42647 & 206.7011 & 2.758885 \\
\hline 6 & -166.006 & -71.194 & -140.346 & -20.3575 \\
\hline 7 & -141.281 & -5.45517 & 23.57421 & -24.6962 \\
\hline 8 & -101.598 & -27.5077 & -38.3278 & -21.3891 \\
\hline 9 & -80.9119 & -11.7167 & -4.82939 & -17.5471 \\
\hline 10 & -61.0079 & -13.3422 & -14.357 & -13.7519 \\
\hline
\end{tabular}

Source: own processing in EViews

In the first period, the number of unemployed does not change as a result to a shock in the number of graduates, the number of faculties or teaching staff. According to the results of Table 6 , in the second period after a shock, $1.4 \%$ of the change in the number of unemployed is explained by the changes in the number of graduates of higher education, $2.95 \%$ of the variation is due to changes in the teaching staff and only $0.46 \%$ of the change in the number of unemployed is 
Simionescu, M., Naroş M.S., (2019)

The unemployment of highly educated people in Romania. A panel VAR approach

attributed to the change in the number of faculties. The influence of changes in the number of graduates and faculties on the number of unemployed increases from one period to the next, while the influence of the changes in the number of unemployed with higher education slightly decreases from one period to the next, but it remains decisive for the variation in the number of unemployed.

Table 6 Decomposition by Variance of the Number of Higher-Education Unemployed

\begin{tabular}{|r|c|r|r|r|r|}
\hline Period & $\begin{array}{c}\text { Standard } \\
\text { Error }\end{array}$ & UNEMPLOYED & GRADUATESS & $\begin{array}{c}\text { TEACHING } \\
\text { STAFF }\end{array}$ & FACULTIES \\
\hline 1 & 932.2144 & 100.0000 & 0.000000 & 0.000000 & 0.000000 \\
\hline 2 & 1180.138 & 95.14569 & 1.429888 & 2.957924 & 0.466501 \\
\hline 3 & 1298.460 & 94.92399 & 1.546124 & 2.620808 & 0.909076 \\
\hline 4 & 1365.215 & 94.31618 & 1.746847 & 2.749632 & 1.187344 \\
\hline 5 & 1402.774 & 94.12318 & 1.812385 & 2.710881 & 1.353554 \\
\hline 6 & 1424.760 & 93.96740 & 1.863259 & 2.719870 & 1.449469 \\
\hline 7 & 1437.586 & 93.89241 & 1.887827 & 2.714381 & 1.505384 \\
\hline 8 & 1445.160 & 93.84391 & 1.903590 & 2.714551 & 1.537949 \\
\hline 9 & 1449.628 & 93.81711 & 1.912312 & 2.713510 & 1.557071 \\
\hline 10 & 1452.275 & 93.80080 & 1.917608 & 2.713271 & 1.568321 \\
\hline
\end{tabular}

Source: own processing in EViews

In the first period, after a shock in the number of faculties and a shock in the teaching staff, in turn, the number of graduates does not change. According to the results of Table 7 , in the first period, $0.24 \%$ of the changes in the number of graduates are due to a shock in the number of unemployed. The influence of changes in the number of unemployed increases slightly from one period to the next, reaching lately to explain $0.688 \%$ of the variation in the number of graduates, while the staff shocks explain about $6.42 \%$ of the variation in the number of graduates of higher education. 
Simionescu, M., Naros M.S., (2019)

The unemployment of highly educated people in Romania. A panel VAR approach

Table 7 Decomposition by Variance of the Number of Higher Education Graduates

(License)

\begin{tabular}{|r|r|r|r|r|r|}
\hline Period & $\begin{array}{c}\text { Standard } \\
\text { Error }\end{array}$ & UNEMPLOYED & GRADUATES & $\begin{array}{c}\text { TEACHING } \\
\text { STAFF }\end{array}$ & FACULTIES \\
\hline 1 & 13097.23 & 0.240103 & 99.75990 & 0.000000 & 0.000000 \\
\hline 2 & 13608.39 & 0.359977 & 92.98217 & 5.466906 & 1.190949 \\
\hline 3 & 13697.71 & 0.579075 & 91.97129 & 6.187284 & 1.262352 \\
\hline 4 & 13717.3 & 0.614434 & 91.73111 & 6.390031 & 1.264426 \\
\hline 5 & 13722.20 & 0.652251 & 91.67547 & 6.408652 & 1.263625 \\
\hline 6 & 13724.12 & 0.666699 & 91.65249 & 6.417315 & 1.263491 \\
\hline 7 & 13724.89 & 0.677220 & 91.64222 & 6.416889 & 1.263673 \\
\hline 8 & 13725.37 & 0.682653 & 91.63629 & 6.417226 & 1.263829 \\
\hline 9 & 13725.2 & 0.686103 & 91.63295 & 6.416999 & 1.263945 \\
\hline 10 & 13725.78 & 0.688062 & 91.63096 & 6.416963 & 1.264017 \\
\hline
\end{tabular}

Source: own processing in EViews

The relationship between the number of unemployed and the other variables is studied through Granger's causality, knowing that the corresponding data series is stationary.

Granger's Causes in the panel, Dumitrescu Hurlin version have the following results at a significance level of $5 \%$ (Table 8 ):

- Causal relationship from the number of graduates to the number of unemployed with higher education;

- $\quad$ Mutual causality relationship between the teaching staff and the number of unemployed with higher education;

- Mutual causality relationship between the number of faculties and the number of unemployed with higher education;

- $\quad$ Mutual causality relationship between the teaching staff and the number of graduates with higher education;

- $\quad$ The causal relationship between the number of faculties and the number of unemployed with higher education. 
Simionescu, M., Naroș M.S., (2019)

The unemployment of highly educated people in Romania. A panel VAR approach

Table 8 Granger variability between variables (Dumitrescu Hurlin version)

\begin{tabular}{|l|c|c|c|}
\hline \multicolumn{1}{|c|}{ Null Hypothesis } & \multicolumn{1}{c|}{ W } & \multicolumn{1}{c|}{ Zbar } & \multicolumn{1}{c|}{ Prob. } \\
\hline $\begin{array}{l}\text { GRADUATES does not homogeneously } \\
\text { cause UNEMPLOYED }\end{array}$ & 16.5569 & 15.2260 & 0.0000 \\
\hline $\begin{array}{l}\text { UNEMPLOYED does not homogeneously } \\
\text { cause GRADUATES }\end{array}$ & 1.96555 & -0.34546 & 0.7297 \\
\hline $\begin{array}{l}\text { PROFESSORS does not homogeneously } \\
\text { cause UNEMPLOYED }\end{array}$ & 13.2291 & 11.9148 & 0.0000 \\
\hline $\begin{array}{l}\text { UNEMPLOYED does not homogeneously } \\
\text { cause PROFESSORS }\end{array}$ & 4.78700 & 2.73674 & 0.0062 \\
\hline $\begin{array}{l}\text { FACULTIES does not homogeneously cause } \\
\text { UNEMPLOYED }\end{array}$ & 16.7202 & 15.7102 & 0.0000 \\
\hline $\begin{array}{l}\text { UNEMPLOYED does not homogeneously } \\
\text { cause FACULTIES }\end{array}$ & 7.28446 & 5.45193 & $5 . \mathrm{E}-08$ \\
\hline $\begin{array}{l}\text { PROFESSORS does not homogeneously } \\
\text { cause GRADUATES }\end{array}$ & 6.83296 & 4.84890 & $1 . \mathrm{E}-06$ \\
\hline $\begin{array}{l}\text { GRADUATES does not homogeneously } \\
\text { cause PROFESSORS }\end{array}$ & 6.26369 & 4.24139 & $2 . \mathrm{E}-05$ \\
\hline $\begin{array}{l}\text { FACULTIES does not homogeneously cause } \\
\text { GRADUATES }\end{array}$ & 6.10343 & 4.07036 & $5 . \mathrm{E}-05$ \\
\hline $\begin{array}{l}\text { GRADUATES does not homogeneously } \\
\text { cause FACULTIES }\end{array}$ & 8.09955 & 6.20057 & $6 . \mathrm{E}-10$ \\
\hline $\begin{array}{l}\text { FACULTIES does not homogeneously cause } \\
\text { PROFESSORS }\end{array}$ & 2.07944 & -0.20686 & 0.8361 \\
\hline $\begin{array}{l}\text { PROFESSORS does not homogeneously } \\
\text { cause FACULTIES }\end{array}$ & 3.87808 & 1.74858 & 0.0804 \\
\hline
\end{tabular}

Source: own processing in Eviews

The tests reject the hypothesis that the number of graduates, faculties and teaching staff is not a cause for the evolution of the number of unemployed with higher education. Therefore, by controlling the variables related to the provision of higher education, the number of unemployed with higher education can be controlled. As the number of graduates increases, the number of teaching staff and the number of faculties increases slightly, and the unemployment rate among people with higher education shows that they have not immediately integrated into the labor market. Our results that show labor market integration difficulties at regional level are confirmed by other studies at national level (Jaba et al., 2010; Bălan, 2014).

In this context, in the case of Romania investing in education and lifelong learning should be based on structural funding and should aim at promoting entrepreneurship. On this line, in 2017, the Managing Authority for the Operational Program Capital Uman launched 5 funding guidelines for projects aimed at reducing unemployment. The projects aim at inserting youth NEETs (people aged 15-24, who are not employed and not integrated into an education or training program), but also other unemployed and inactive people. On the other 
Simionescu, M., Naros M.S., (2019)

The unemployment of highly educated people in Romania. A panel VAR approach

hand, it is necessary for employees to participate in short-term vocational training programs to help them adapt more easily to the job requirements.

\section{Conclusions}

Based on empirical results at macroeconomic level, several recommendations will be formulated: it is useful to integrate students into the labor market before completing their studies, to gain the necessary work experience; incentives should be given to companies that employ fresh graduates who have not worked yet; it may be useful for companies run more internships, in order to select employees from the students. The expansion of the educational offer also increases the number of university graduates, and the number of existing faculties is sufficient to ensure graduates' insertion into the labor market.

The analysis to the regional level based on the VAR model in the panel suggests difficulties in the long-term absorption of graduates on the labor market in Romania. Due to the fact that the education system produces qualified persons in fields for which there is no demand on the labor market, employment is made more difficult the lack of jobs leads to the increase of unemployment among young people. Therefore, policies to diversify the educational offer from higher education institutions are needed to respond to labor market needs and to increase the number of specialists. Thus, the existence of a system to monitor the relationship between educational supply and current demand would prevent system failures and speed up economic growth, creating new jobs and increasing labor demand. Therefore, it is important that the state to embalances the number of specialists in some fields (areas) for to garanted the integration on the labor market a teaching staff . It is necessary a flexible curriculum oriented on the labor market as well as a reorganization of the graduates' structure by professions and occupational groups. This approach is limited by the consideration of only few variables in the panel VAR model. Therefore, in a future study more variables should be consiered.

\section{Acknowledgements}

In this section you can acknowledge any support given which is not covered by the author contribution or funding sections. This may include administrative and technical support, or donations in kind (e.g., materials used for experiments).

E.g.: The authors thank the anonymous reviewers and editor for their valuable contribution.

\section{Funding}

This research received no external funding.

32 S sciendo Studia Universitatis "Vasile Goldis" Arad. Economics Series Vol 29 Issue 3/2019 ISSN: 1584-2339; (online) ISSN: 2285 - 3065

Web: publicatii.uvvg.ro/index.php/studiaeconomia. Pages $20-37$ 
Simionescu, M., Naroș M.S., (2019)

The unemployment of highly educated people in Romania. A panel VAR approach

\section{Author's Contributions}

Mihaela Simionescu conceived the study and was responsible for the methodology and data collection and empirical analysis, model estimation in EViews software, conclusions, review and editing.

Maria-Simona Naroș was responsible for the introduction and literature review section, editing.

\section{Disclosure Statement}

The authors declare no conflict of interest.

\section{References}

1. Anderson, C.A., \& Bowman, M.J., (Eds.), (1966), Education and economic development, Aldine Pub. Co.

2. Anderson, C.A., \& Bowman, M.J., (1963), Concerning the Role of Education in Development, London, Collier Macmillan.

3. Bălan, M., (2014), Youth labour market evolutions at regional level in Romania, Internal Auditing \& Risk Management, 2(34), pp. 29-37.

4. Bălan, M., Uzlău, C., \& Ene, C.M., (2013), Transition from Educational System to Labour Market in Romania, Procedia-Social and Behavioral Sciences, 92, pp. 314-322.

5. Bassi, M., \& Galiani, S., (2009), Labor market insertion of young adults in Chile, Banco Interamericano de Desarrollo, Washington, DC.

6. Bell, D.N., \& Blanchflower, D.G., (2011), Young people and the Great Recession, Oxford Review of Economic Policy, 27(2), pp. 241-267.

7. Ben Hamida, Z.N., (2014), Higher Education and Labor Market Diploma Effect and Over-education Case of Tunisian Higher Education Graduates, Review of Arts and Humanities, March 2014, 3(1), pp. 1-21.

8. Blanchflower D.G., Freeman R.B., (2000), Youth employment and joblessness in advanced countries, University of Chicago Press.

9. Boeri, T., \& van Ours, J., (2008), The economics of imperfect labor markets, Princeton University Press, Princeton, USA.

10. Boockmann, B., \& Steffes, S., (2010), Workers, firms, or institutions: What determines job duration for male employees in Germany? Industrial and Labor Relations Review, 64(1), pp. 109-127.

11. Braica, A.P., (2015), Managing the Current Situation of Young People in National and European Context in Terms of their Employment, Studia Universitatis „Vasile Goldis” Arad, Economics Series, 25(1), pp. 74-91.

12. Burgess, S., (1999), Reallocation of labour: An international comparison using job tenure data, London School of Economics and Political Science, London.

13. Canova, F., \& Ciccarelli, M., (2006), Estimating Multi-Country VAR Models,

S sciendo Studia Universitatis "Vasile Goldis" Arad. Economics Series Vol 29 Issue 3/2019 
Simionescu, M., Naros M.S., (2019)

The unemployment of highly educated people in Romania. A panel VAR approach

European Central Bank Working Paper, 603, pp. 1-35.

14. Clark, K.B., \& Summers, L.H., (1982), The dynamics of youth unemployment, in Freeman, R.B. and D.A. Wise, (editors), The Youth Labor Market Problem: Its Nature, Causes, and Consequences, University of Chicago Press and NBER, pp. 199-234.

15. Cordazzo, P., \& Jaoul-Grammare, M., (2015), How Master's Level Graduates Fare On The Labor Market: 'Objective' and 'Subjective' Measurement, Accepte pour publication dans Journal of Reviews on Global Economics mais non publie (choix des a.. 2015. <halshs-01101020>, pp. 1-19.

16. Davies, A., Fidler, D., \& Gorbis, M., (2011), Future work skills 2020, Institute for the Future for University of Phoenix Research Institute, 540, pp. 1-14.

17. Elias, P., \& Purcell, K., (2004), Is mass higher education working? Evidence from the labour market experiences of recent graduates, National Institute Economic Review, 190(1), pp. 60-74.

18. Eurofound, (2015), Job tenure in turbulent times, Publications Office of the European Union, Luxembourg.

19. Freeman, R.B., (1976), The overeducated american, Academic Press, New York.

20. Freeman, R.B., (1979), The Effect of Demographic Factors on Age Earnings Profiles, Journal of human resources, 14(3), pp. 289-318.

21. Goodhart, A.E., \& Hofmann, B., (2008), House Prices, Money, Credit, and the Macroeconomy, Oxford Review of Economic Policy, 24, pp. 180-205.

22. Goody, I., \& Watt, A., (1968), The Consequences of Literacy, Cambridge, Cambridge University Press.

23. Groot, W., \& Van Den Brink, H.M., (2000), Overeducation in the labor market: a meta-analysis, Economics of education review, 19(2), pp. 149-158.

24. Inkeles, A., \& Holsinger, D.B., (1974), Education and Individual Modernity in Developing Countries, Leiden, Brill.

25. Jaba, E., Bălan, C., Roman, M., \& Roman, M., (2010), Statistical evaluation of spatial concentration of unemployment by gender, MPRA, 25161, pp. 1-17.

26. Krueger, A., \& Lindahl, M., (2000), Education for Growth: Why and for Whom?, NBER Working Paper, 7591, pp. 1-34.

27. Lawton, W., Ahmed, M., Angulo, T., Axel-Berg, A., Burrows, A., \& Katsomitros, A., (2013), Horizon scanning: What will higher education look like in 2020, UK HE International Unit.

28. McClelland, D.C., \& Winter, D.G., (1969), Motivating Economic Achievement, New York, Free Press.

29. McGuinness, S., (2006), Overeducation in the labour market, Journal of economic surveys, 20(3), pp. 387-418.

34 S sciendo Studia Universitatis "Vasile Goldis" Arad. Economics Series Vol 29 Issue 3/2019 ISSN: 1584-2339; (online) ISSN: 2285 - 3065

Web: publicatii.uvvg.ro/index.php/studiaeconomia. Pages $20-37$ 
Simionescu, M., Naroș M.S., (2019)

The unemployment of highly educated people in Romania. A panel VAR approach

30. Meakin, S., (1992), The Rio earth summit: summary of the united nations conference on environment and development (Vol. 317), Library of Parliament, Research Branch.

31. Moore, J., (2016), Higher Education Reflecting Income Inequality. Explorations in Adult Higher Education, Occasional paper Series, 1(2016), pp. 3583.

32. Naroș, M.S., (2018), Romanian economists and the labour market, Czech Journal of Social Sciences, Business and Economics, 7(1), pp. 1-10.

33. OECD, (2001), The Well-being of Nations, The Role of Human and Social Capital, Centre for Educational Research and Innovation, OECD Publications, Paris.

34. Psacharopoulos, G., (1984), The Contribution of Education to Economic Growth: International Comparisons, Cambridge, Ballinger Publishing Co.

35. Psacharopoulos, G., (1994), Returns to Investment in Education: A Global Update, World Development, 22(9), pp. 1325-1343.

36. Psacharopoulos, G., (2014), The returns to investment in higher education, Using Data to Improve Higher Education, 1, pp. 121-148.

37. Salas-Velasco, M., (2007), The transition from higher education to employment in Europe: the analysis of the time to obtain the first job, Higher Education, 54(3), pp. 333-360.

38. Schomburg, H., \& Teichler, U., (2007), Higher education and graduate employment in Europe: results from graduates surveys from twelve countries (Vol. 15), Springer Science \& Business Media.

39. Simionescu, M., (2013), Econometrie avansată, Editura Universitară, București. 40. Teichler, U., \& Kehm, B.M., (1995), Towards a new understanding of the relationships between higher education and employment, European journal of education, 30(2), pp. 115-132.

41. Teselios, D., \& Albici, M., (2012), Utilizarea Sondajului Statistic în Economie, Strategii Manageriale, 2(16), pp. 40-45.

42. Vasile, V., \& Vasile, L., (2011), Youths on labour market. Features. Particularities. Pro-mobility factors for graduates. Elements of a balanced policy for labour migration, Romanian Journal of Economics, 32(1), pp. 41-60.

\section{Appendix}

Pearson correlation coefficients

\begin{tabular}{|l|r|r|r|r|}
\hline & UNEMPLOYED & GRADUATE & \multicolumn{1}{l|}{ PROFESSORS } & \multicolumn{1}{l|}{ FACULTIES } \\
\hline UNEMPLOYED & 1 & -0.08043 & -0.08076 & -0.10772 \\
\hline GRADUATES & -0.08043 & 1 & 0.61761 & 0.643863 \\
\hline PROFESSORS & -0.08076 & 0.61761 & 1 & 0.938329 \\
\hline FACULTIES & -0.10772 & 0.643863 & 0.938329 & 1 \\
\hline
\end{tabular}


Simionescu, M., Naroş M.S., (2019)

The unemployment of highly educated people in Romania. A panel VAR approach

\begin{tabular}{|c|c|c|c|c|c|c|}
\hline \multicolumn{3}{|c|}{ VAR Lag Order Selection Criteria } & & & & \\
\hline Lag & LogL & LR & FPE & AIC & SC & HQ \\
\hline 0 & -3368.723 & NA & $6.18 \mathrm{e}+23$ & 66.13182 & 66.23476 & 66.17350 \\
\hline 1 & -3306.987 & 117.4179 & $2.52 \mathrm{e}+23$ & 65.23505 & $65.74975^{*}$ & 65.44347 \\
\hline 2 & -3275.225 & 57.92037 & $1.85 \mathrm{e}+23$ & 64.92597 & 65.85244 & 65.30113 \\
\hline 3 & -3242.027 & 57.93252 & $1.33 \mathrm{e}+23$ & 64.58877 & 65.92699 & 65.13066 \\
\hline 4 & -3214.460 & $45.94596^{*}$ & $1.07 \mathrm{e}+23 *$ & $64.36196^{*}$ & 66.11194 & $65.07058^{*}$ \\
\hline * indicates lag order selected by the criterion \\
LR: sequential modified LR test statistic (each test at 5\% level) \\
FPE: Final prediction error \\
AIC: Akaike information criterion \\
SC: Schwarz information criterion \\
HQ: Hannan-Quinn information criterion \\
\hline
\end{tabular}

\begin{tabular}{|c|c|c|c|c|}
\hline & UNEMPLOYED & GRADUATES & PROFESSORS & FACULTIES \\
\hline \multirow[t]{3}{*}{ UNEMPLOYED(-1) } & 0.766019 & -0.600576 & 0.000396 & 0.000302 \\
\hline & $(0.04832)$ & $(0.67881)$ & $(0.12761)$ & $(0.00213)$ \\
\hline & [ 15.8546$]$ & {$[-0.88475]$} & {$[0.00310]$} & {$[0.14154]$} \\
\hline \multirow[t]{3}{*}{ GRADUATES(-1) } & -0.002636 & 0.073518 & 0.027076 & 0.000440 \\
\hline & $(0.00715)$ & $(0.10045)$ & $(0.01888)$ & $(0.00032)$ \\
\hline & {$[-0.36864]$} & {$[0.73186]$} & {$[1.43377]$} & [1.39259] \\
\hline \multirow[t]{3}{*}{ PROFESSORS(-1) } & 0.020200 & -3.167912 & -0.612678 & -0.014114 \\
\hline & $(0.07801)$ & $(1.09608)$ & $(0.20605)$ & $(0.00344)$ \\
\hline & {$[0.25893]$} & {$[-2.89023]$} & {$[-2.97341]$} & {$[-4.09723]$} \\
\hline \multirow[t]{3}{*}{ FACULTIES(-1) } & 5.735523 & 105.6736 & 6.488856 & 0.425477 \\
\hline & $(4.91897)$ & $(69.1095)$ & $(12.9919)$ & $(0.21719)$ \\
\hline & {$[1.16600]$} & {$[1.52907]$} & {$[0.49945]$} & {$[1.95900]$} \\
\hline \multirow[t]{3}{*}{$\mathrm{C}$} & 286.2620 & 17579.32 & 4626.986 & 83.69669 \\
\hline & $(229.579)$ & $(3225.49)$ & $(606.363)$ & $(10.1368)$ \\
\hline & [1.24690] & {$[5.45012]$} & {$[7.63072]$} & {$[8.25673]$} \\
\hline R-squared & 0.621598 & 0.093941 & 0.200519 & 0.182759 \\
\hline Adj. R-squared & 0.611957 & 0.070856 & 0.180150 & 0.161938 \\
\hline Sum sq. resids & $1.36 \mathrm{E}+08$ & $2.69 \mathrm{E}+10$ & $9.52 \mathrm{E}+08$ & 265990.3 \\
\hline S.E. equation & 932.2144 & 13097.23 & 2462.156 & 41.16073 \\
\hline F-statistic & 64.47566 & 4.069462 & 9.844330 & 8.777467 \\
\hline Log likelihood & -1335.014 & -1763.114 & -1492.353 & -829.5612 \\
\hline Akaike AIC & 16.54338 & 21.82857 & 18.48584 & 10.30322 \\
\hline Schwarz SC & 16.63868 & 21.92386 & 18.58114 & 10.39852 \\
\hline Mean dependent & 3155.926 & 13580.24 & 3318.062 & 73.24074 \\
\hline S.D. dependent & 1496.497 & 13587.45 & 2719.244 & 44.96193 \\
\hline \multicolumn{2}{|c|}{ Determinant resid covariance (dof adj.) } & $1.12 \mathrm{E}+23$ & & \\
\hline \multicolumn{2}{|c|}{ Determinant resid covariance } & $9.90 \mathrm{E}+22$ & & \\
\hline \multicolumn{2}{|c|}{ Log likelihood } & -5208.408 & & \\
\hline \multicolumn{2}{|c|}{ Akaike information criterion } & 64.54824 & & \\
\hline \multicolumn{2}{|c|}{ Schwarz criterion } & 64.92943 & & \\
\hline
\end{tabular}


Simionescu, M., Naros M.S., (2019)

The unemployment of highly educated people in Romania. A panel VAR approach

\begin{tabular}{|c|c|c|}
\hline \multicolumn{3}{|c|}{ VAR Residual Portmanteau Tests for Autocorrelations } \\
\hline \multicolumn{2}{|c|}{ Null Hypothesis: no residual autocorrelations up to lag h } \\
\hline Lags & Q-Stat & Prob. \\
\hline 1 & 28.38786 & NA* \\
\hline 2 & 10.76435 & 0.8238 \\
\hline 3 & 13.83510 & 0.6110 \\
\hline 4 & 11.35810 & 0.7869 \\
\hline 5 & 22.16937 & 0.1378 \\
\hline 6 & 12.10079 & 0.7370 \\
\hline 7 & 20.58304 & 0.1951 \\
\hline 8 & 31.02806 & 0.1334 \\
\hline 9 & 28.38786 & 0.2843 \\
\hline 10 & 10.76435 & 0.8238 \\
\hline
\end{tabular}

\begin{tabular}{|c|c|c|}
\hline VAR Residu & das & s (only \\
\hline Joint test: & & \\
\hline Chi-sq & $\mathrm{df}$ & Prob. \\
\hline 0.453 & 80 & 0.665 \\
\hline
\end{tabular}

\begin{tabular}{|c|c|c|c|}
\hline Component & Jarque-Bera & df & Prob. \\
\hline 1 & 1.761443 & 2 & 0.4145 \\
\hline 2 & 1436.310 & 2 & 0.0000 \\
\hline 3 & 50.69965 & 2 & 0.0000 \\
\hline 4 & 22.60889 & 2 & 0.0000 \\
\hline Joint & 1511.380 & 8 & 0.0000 \\
\hline
\end{tabular}

\begin{tabular}{|l|r|r|c|}
\hline \multicolumn{4}{|l|}{ Sairwise Dumitrescu Hurlin Panel Causality Tests 19932017} \\
\hline \multicolumn{4}{|c|}{ Sample } \\
\hline Null Hypothesis: & W-Stat. & Zbar-Stat. & Prob. \\
\hline GRADUATES does not homogeneously cause UNEMPLOYED & 16.5569 & 15.2260 & 0.0000 \\
\hline UNEMPLOYED does not homogeneously cause GRADUATES & 1.96555 & -0.34546 & 0.7297 \\
\hline PROFESSORS does not homogeneously cause UNEMPLOYED & 13.2291 & 11.9148 & 0.0000 \\
\hline UNEMPLOYED does not homogeneously cause PROFESSORS & 4.78700 & 2.73674 & 0.0062 \\
\hline FACULTIES does not homogeneously cause UNEMPLOYED & 16.7202 & 15.7102 & 0.0000 \\
\hline UNEMPLOYED does not homogeneously cause FACULTIES & 7.28446 & 5.45193 & 5. E-08 \\
\hline PROFESSORS does not homogeneously cause GRADUATES & 6.83296 & 4.84890 & 1. E-06 \\
\hline GRADUATES does not homogeneously cause PROFESSORS & 6.26369 & 4.24139 & 2. E-05 \\
\hline FACULTIES does not homogeneously cause GRADUATES & 6.10343 & 4.07036 & 5. E-05 \\
\hline GRADUATES does not homogeneously cause FACULTIES & 8.09955 & 6.20057 & $6 . E-10$ \\
\hline FACULTIES does not homogeneously cause PROFESSORS & 2.07944 & -0.20686 & 0.8361 \\
\hline PROFESSORS does not homogeneously cause FACULTIES & 3.87808 & 1.74858 & 0.0804 \\
\hline
\end{tabular}

